\title{
排煙脱硫石膏および高炉水砕スラグを使用した 安定処理土における反応生成物と強度特性 REACTION PRODUCTS AND STRENGTH CHARACTERISTICS IN
STABILIZED SOIL USING FLUE GAS DESULFURIZATION BY-
PRODUCT AND GRANULATED BLASTFURNACE SLAG
}

\author{
枷 場 重 正*・川 村 満 紀** - 鳥 居 和 之*** \\ By Shigemasa HASABA, Mitsunori KAWAMURA and Kazuyuki TORII
}

\section{1. まえがき}

最近，省資源および省エネルギーの立場より未利用資 源の活用が重要課題として取り上げられると同時に, 年 年増加の一途をたどる産業副生産物の再利用がさまざま の分野において注目を集めている.

排煙脱硫石衰（以下，排脱石塾と称す）および高炉水 砕スラグは，それぞれ火力発電所等における亜硫酸ガス の処理および鉄鋼生産において多量に発生する産業副生 産物であり, 現在供給過剩となっているものである.

排脱石育および高炉水砕スラグは，発生する各施設ご とに物理的性質および化学成分が異なる場合があり, ま た地域によりこれら産業副生産物の需給関係が相違する ため, 各地域の実状に応じた建設材料としての有効利用 の開発が望まれる.

排脱石亭および高炉水砕スラグは，それらの化学成分 から考えて, 消石灰またはセメントとともに使用すれ ば，土質安定材として道路における路床土および路盤の 改良, 盛土における法面の安定処理等幅広く利用が可能 であると思われる，有泉抢よび大場は，消石灰掞よび石 育によって処理したアロファン質粘土に関して一連の実 験を行い, 消石灰一石育-アロファン質粘土混合物におけ る化学反応の機構, 強度発生の状況および安定処理を行 う場合の諸条件を明らかにしている

消石灰（またはセメント）-石亮処理土においては, 粘 土鉱物と消石灰（またはセメント）閒の反応による反応 生成物以外に, 粘土鉱物より供給されるアルミナと石灰 および石塾間の反忘によって生成されるエトリンガイト が安定処理土の強度および膨張の発生に重要な役割を果

* 正会員 工博 金沢大学教授 工学部土木工学科

** 正会員 工博 金沢大学教授 複合材料応用研究センター *** 正会員 工修 金沢大学助手 工学部土木工学科
たすと思われる3)。

消石灰（またはセメント)-石膏処理土におけるエトリ ンガイト生成には粘土鉱物よりアルミナが供給される必 要があるため, 本処理土においてはアルミナ分を多く含 み，石灰との反応性が高い粘性土が有効であるといわれ ている、したがって，アルミナ分の不足する土に対して は高炉スラグおよび赤泥等をアルミナ供給源として添加 することによってより大きな処理効果が期待できるもの と思われる。

消石灰（また注セメント)-石高一高炉スラグ処理土に おいては，エトリンガイト，モノサルフェート水和物お よび消石灰と粘土間の反応生成物 (ポゾラン反応生成物) が生成すると考えられる．しかし，このような締固め安 定処理土におうる安定材の混合割合, 反応条件（温度お よび水分の供給状態）および反応㑺わる粘土鉱物の種 類が反応生成物の種類, 形態掞よび生成量に及ぼす影響 については不明な点が多く残されている.さらに最適含 水比で締め固められた消石灰（またはセメント）石高高炉スラグ処理土における反応生成物の特徵および反応 生成物が処理土の強度および膨張に及ぼす影響について は，ほとんど明らかにされていない。

本論文は物理的性質, 化学成分および粘土鈗物組成の 異なる 2 種類の土に消石灰 (またはセメント), 排脱石 高および高炉水砕スラグを種々の混合割合で添加したと きの初期材令から長期材令に招ける安定材の混合割合と 一軸圧縮強度および体積膨張との関係について明らかに するとともに, 本処理土において生成するエトリンガイ トおよびポゾラン反応生成物の種類, 生成量および形態 が試料土の種類および安定材の混合割合によってどのよ らに変化するかを示差熱分析，X線回折および走査型電 子顕微鏡観察により調べたものである.さらに本論文で は, 反応生成物の種類, 生成量および形態が安定処理土 の強度および膨張特性に及ぼす影響について考察してい 
る. また, 実用的観点から, 本処理土において得られた 結果とセメントおよび石灰処理土の諸性質との相違を明 確にすることによって，排脱石高および高炉スラグを土 質安定材として使用することの有効性および実際に安定 処理に適用する場合における問題点について検討する.

\section{2. 実 験 概 要}

\section{(1) 使用材料}

本実験に使用した 2 種類の試料土は, 室内において長 期間自然乾燥させ，所定粒度にときほぐしたものであ る.

試料土の物理的性質および化学成分は, それぞれ表一 1 および表一2 に示すと括りである. 排脱石高 ( $\mathrm{H}$ 電力 （株）産）の主成分は, 約 $8 \%$ の付着水を含む 2 水石高 であり, 排脱石育の SEM 像抢よび DTA 曲線は 写真一 1 および 図一1 に示すとおりである. 使用した高炉水砕 スラグ粉末 ( $\mathrm{K}$ 製鉄 (株) 製) は，スラグをボールミル

表一1 試料土の物理的性質

\begin{tabular}{|c|c|c|c|c|}
\hline & & & 粘 性 土 & 砂 質 土 \\
\hline & 分 & 類 & 粘土ローム & 砂質ローム \\
\hline 砂 & & $(\%)$ & 41.0 & 76.5 \\
\hline v & 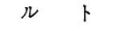 & $(\%)$ & 30.0 & 17.5 \\
\hline 粘 & \pm & $(\%)$ & 29.0 & 6.0 \\
\hline & 性 限 & $(\%)$ & 50.6 & - \\
\hline 塑 & 性 限 & $(\%)$ & 23.1 & - \\
\hline 塑 & 性＼cjkstart指 & 数 & 27.5 & - \\
\hline & 適 含 水 & 比 $\quad(\%)$ & 26.0 & 23.4 \\
\hline & 大 乾 蜗 密 & 度 $\left(\mathrm{g} / \mathrm{cm}^{8}\right)$ & 1.530 & 1.570 \\
\hline 比 & & 重 & 2.723 & 2.677 \\
\hline
\end{tabular}

\begin{tabular}{c|c|c}
\multicolumn{2}{c}{ 表一2 } & \multicolumn{2}{c}{ 試料土の化学成分 (\%) } \\
\hline & 粘 性 土 & 砂 質 土 \\
\hline lg. Loss & 8.51 & 4.08 \\
$\mathrm{SiO}_{2}$ & 62.83 & 60.92 \\
$\mathrm{Al}_{2} \mathrm{O}_{3}$ & 17.07 & 12.46 \\
$\mathrm{Fe}_{2} \mathrm{O}_{3}$ & 6.19 & 14.31 \\
$\mathrm{CaO}$ & 0.60 & 0.16 \\
$\mathrm{MgO}$ & 1.92 & 3.88 \\
$\mathrm{~K}_{2} \mathrm{O}$ & 0.72 & 1.20 \\
$\mathrm{Na}_{2} \mathrm{O}$ & 0.30 & 1.91 \\
\hline
\end{tabular}

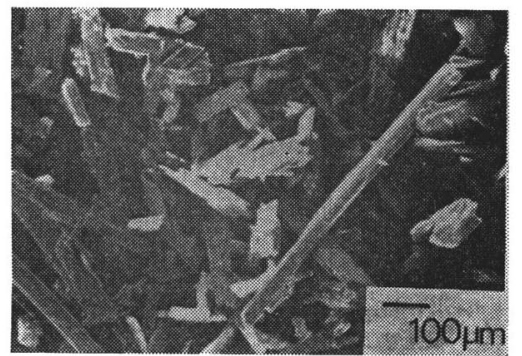

写真一1 排脱石亳粒子の SEM 像
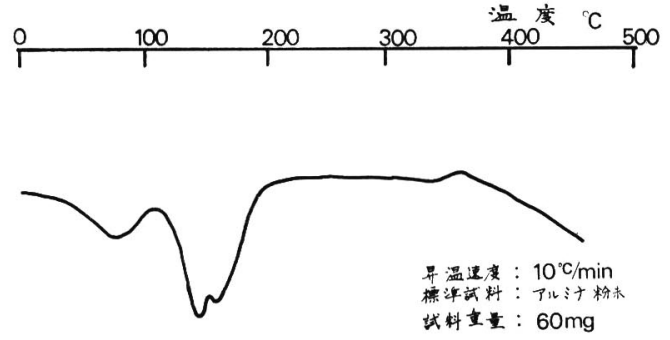

図一1排脱石膏の DTA 曲線

表一3 排脱石膏の 鉱物組成お よび化学成分 $(\%)$

\begin{tabular}{l|r}
\hline $\mathrm{CaSO}_{4} \cdot 2 \mathrm{H}_{2} \mathrm{O}$ & 96.71 \\
$\mathrm{CaSO}_{4} \cdot 1 / 2 \mathrm{H}_{2} \mathrm{O}$ & 0.06 \\
$\mathrm{MgSO}_{4}$ & 1.23 \\
$\mathrm{SiO}_{2}+\mathrm{C}$ & 0.53 \\
$\mathrm{Al}_{2} \mathrm{O}_{3}+\mathrm{Fe}_{2} \mathrm{O}_{3}$ & 1.51 \\
\hline
\end{tabular}

表一4 高炉水砕スラグの 化学成分 (\%)

\begin{tabular}{l|r}
\hline $\mathrm{SiO}_{2}$ & 33.74 \\
$\mathrm{Al}_{2} \mathrm{O}_{3}$ & 15.82 \\
$\mathrm{CaO}$ & 39.61 \\
$\mathrm{MgO}$ & 8.39 \\
\hline
\end{tabular}

によって粉砕し， $88 \mu \mathrm{m}$ ふるいを通過させたものであ る. 排脱石膏および高炉水砕スラグの鉱物組成および化 学成分は，それぞれ 表一3 および 表一4 に示すとおり である. 本実験に使用したセメントおよび消石灰は，普 通ポルトランドセメント ( $\mathrm{N}$ 社製) および工業用消石灰 である。

\section{（2）供試体の種類}

消石灰(またはセメント)-排脱石高高炬スラグの各組 合せについて安定材の添加量は, 試料土の乾燥重量の $10 \%$ および 20\% である. 各安定材の混合割合について は, 添加する全安定材量の $1 / 2$ は消石灰（またはセメン ト）であり，残りの $1 / 2$ は排脱石膏および高炉スラグで ある.さらに，排脱石膏の高炬 スラグに対する比率を $5,3,1,1 / 3$, および $1 / 5$ と変化させた.

\section{（3）実験方法}

a)一軸圧縮強度試験

供試体は直径 $5 \mathrm{~cm}$, 高さ $10 \mathrm{~cm}$ の円柱体であり, 締 固め試験（JIS A 1210）によって求めた最適含水比およ び最大乾燥密度（表一5 参照）となるように静的に締め

表一5 各種安定処理土の締固め試験結果

\begin{tabular}{|c|c|c|c|c|}
\hline \multirow{2}{*}{ 混合割合 $(\%)$} & 粘 性 & 土 & 砂 & 土 \\
\hline & $\begin{array}{c}\text { 最大乾燥密度 } \\
\left(\mathrm{g} / \mathrm{cm}^{8}\right)\end{array}$ & $\begin{array}{c}\text { 最適含水比 } \\
(\%)\end{array}$ & $\begin{array}{c}\text { 最大乾燥密度 } \\
\left(\mathrm{g} / \mathrm{cm}^{3}\right)\end{array}$ & $\begin{array}{c}\text { 最適含水比 } \\
(\%)\end{array}$ \\
\hline 消 石 屁 & 1.504 & 25.5 & 1.524 & 22.0 \\
\hline 消石灰-石高 （10-10） & 1.484 & 27.4 & 1.532 & 20.5 \\
\hline $\begin{array}{r}\text { 消石灭-石育-スラケ } \\
(10-5-5)\end{array}$ & 1.434 & 27.5 & 1.526 & 20.1 \\
\hline 消石欧ースラケ $(10-10)$ & 1.450 & 27.5 & 1.542 & 20.0 \\
\hline セメント & 1.580 & 25.3 & 1.584 & 20.5 \\
\hline セメントー石言 (10-10) & 1.542 & 26.4 & 1.548 & 21.5 \\
\hline $\begin{array}{r}\text { セメントー石高-スラク } \\
(10-5-5)\end{array}$ & 1.519 & 26.0 & 1.555 & 20.9 \\
\hline セメントースラゲ & 1.512 & 25.9 & 1.589 & 18.8 \\
\hline
\end{tabular}


固めたものである.

供試体は作成後ポリエチレン袋中に密封した状態で所 定期間中恒温恒湿室内 $\left(20^{\circ} \mathrm{C}, \mathrm{RH} 95 \%\right)$ で養生した.

載荷速度は $0.2 \mathrm{~kg} / \mathrm{cm}^{2} / \mathrm{sec}$ であり，実験值はすべて 3 個の平均である.

b) 示差熱分析 (DTA), X 線回折および $\mathrm{pH}$ 試験 強度試験用供試体の断片を指頭に感じなくなるまで粉 砕した粉末試料 (乾燥方法 : 自然乾燥) について, サー モフレックス (昇温速度 : $10^{\circ} \mathrm{K} / \mathrm{min}$, 標準試料 : アルミ ナ粉末, 理学電気社製) および $\mathrm{X}$ 線ディフラクトメー ター $(\mathrm{CuK} \alpha, \mathrm{Ni}$ フィルター, $30 \mathrm{kV}, 15 \mathrm{~mA}$, 島津社 製）を使用することによって示差熱分析曲線および $\mathrm{X}$ 線回折図形を得た。 また，同様の粉末試料 $10 \mathrm{~g}$ と蒸留 水 $50 \mathrm{cc}$ を 10 分間擋拌後乃過した浸出液の $\mathrm{pH}$ を測定 した.

c） 走査型電子顕微鏡 (SEM) による反応生成物の観 察

圧縮強度試験の供試体破断面中央部より採取した試料 およびマイクロハイドレーションの手法4)により試料台 上で試料土と安定材とを直接反応させることによって作 成した試料を真空乾燥後, 炭素および金で蒸着し, 走査 型電子顕微鏡（ASM-SX，島津社製）により SEM 像を 得た.

3. 消石灰 (またはセメント)-排脱石亳一高师ス ラグ処理土の一軸圧縮強度および体積膨張

\section{（1）一軸圧縮強度}

図一2 および 図一3 は，粘性土を使用した消石灰（ま

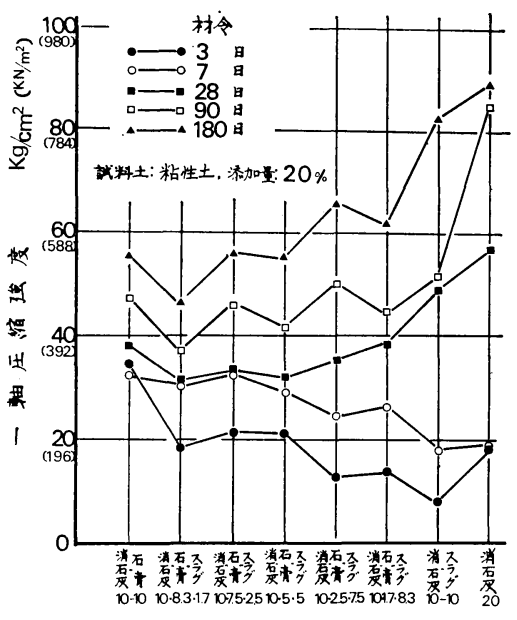

湜合到合 $(\%)$

図一2 消石灰-排脱石音一高炉スラグ好理土（試料土： 粘性土, 安定材添加量：20\%）の安定材の混合 割合と一軸圧縮強度の関係

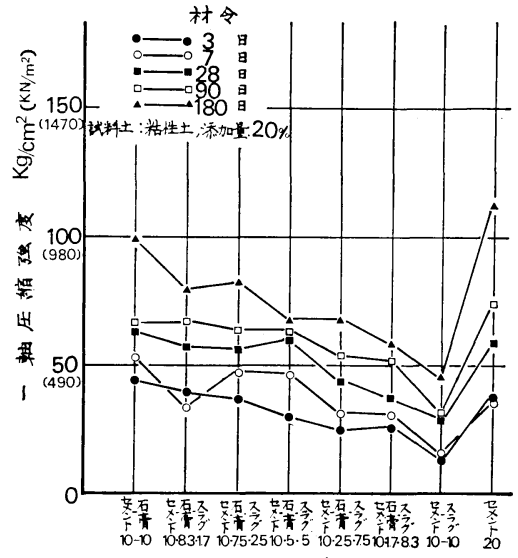

湿合割 合( $\%$

図一3 セメントー排脱石高一高炉スラグ処理土（試料 土 : 粘性土, 安定材添加量 : 20\%) の安定材 の混合割合と一軸圧縮強度の関係

たはセメント)-排脱石膏-高炉 スラグ 処理土（安定材添 加量：20\%）の各材令における一軸圧縮強度と安定材の 混合割合の関係を示したものである. 添加された排脱石 亮および消石灰は，セメントの水和反忘により供給され るアルミナおよび粘土および高炉スラグに含まれるアル ミナ分とすみやかに反応し，エトリンガイトの針状結晶 を多量に生成する. 本処理土における初期材令の強度増 加にはこのエトリンガイトが大きな役割を果たしている ものと思われる。

消石灰一排脱石膏一高炉スラグ処理土においては 7 日材 令までの初期材令では主としてエトリンガイトの生成が 強度に貢献しており，このため排脱石膏の添加量の多い ものほど強度が大きく，石高の一部を高炉スラグで置換 しない消石灰一排脱石亮処理土が最大の強度を示す. し かし，28日材令以後の長期材令では消石灰と粘土間の反 応および消石灰による高炉スラグの潜在水硬性の発揮が 活発となるため, 高炉スラグの添加量の多いものほど強 度の伸びが著しい. 28 日材令以後では消石灰処理土の強 度が最大となり，ついで消石灰一高炉スラグ処理土が高 い強度を示す．セメントー排脱石高高炬スラグ処理土に おいても，消石灰一排脱石高-高炉スラグ処理土と同様に 初期材令で主としてエトリンガイトの生成が強度に貢献 するようである.しかし，消石灰一排脱石高一高炉スラグ 処理土においてみられるような高炉スラグの添加による 効果注顕著ではなく，セメントー高炉スラグ処理土の強 度は全材令において最も低い。

以上のように，粘性土では消石灰またはセメント処理 土における消石灰またはセメントの一部を排脱石膏およ び高炉スラグで置き換えることにより，使用する消石灰 またはセメントの量を減少できる．排脱石高の添加量の 多い混合割合のものは消石灰またはセメント処理土より 


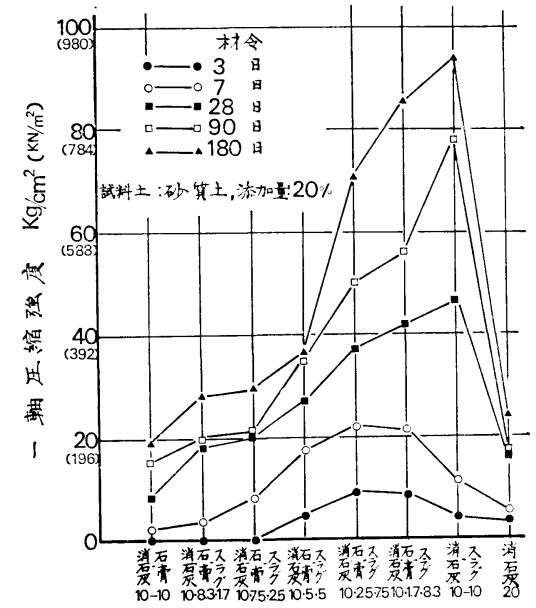

混合刺合 $(\%)$

図-4 消石灰-排脱石書一高炉スラグ好理土（試料土： 砂質土, 安定材添加量 : 20\%) の安定材の混合 割合と一軸圧縮強度の関係

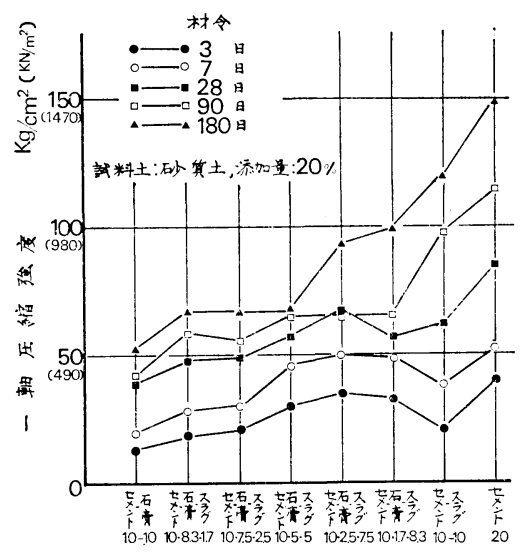

湜合割合 $(\%)$

図一5 セメントー排脱石高一高炉スラグ処理土（試料 土 : 砂質土, 安定材添加量 : 20\%) の安定材 の混合割合と一軸圧縮強度の関係

も大きな初期強度を示し, 高炉スラグの添加量の多い混 合割合のものは長期材令における強度の増大が顕著であ る.

次に図一4 および図一5 は，砂質土を使用した消石灰 (またはセメント)-排脱石高高炉スラグ処理土（安定材 添加量：20\%）の各材令における一軸圧縮強度と安定材 の混合割合との関係を示したものである. 一般に，砂質 土においては反応性アルミナおよびシリカ分が少ないた め, 消石灰と粘土間の反応およびエトリンガイトの生成 反応は粘性土の場合ほど活発でない，さらに，土粒子間 に粘着力をもたない砂質土を使用した処理土はエトリン ガイトの生成時に膨張を示し, 膨張量の大きいものでは 強度が低下寸る (図一4 および 図一8 参照)。したがっ て, 初期材令では適量のエトリンガイトを生成する混合
割合が最大の強度を示し, 消石灰（またはセメント）-排 脱石亮一高炉スラグ処理土においては消石灰（またはセ メント)-排脱石高高炉スラグ (10\%-2.5\%-7.5\%)の混 合割合のものが最大の強度を示す. しかし，28日材令以 後は両処理土とも高叔スラグの潜在水硬性の発揮による 効果が粘性土を使用した処理土以上に現われていくため に, 高炉スラグ添加量の多い混合割合のものの強度の伸 びが著しい。

以上のように，砂質土では消石灰またはセメント処理 土における消石灰またはセメントの一部を排脱石高およ び高炉スラグで置き換えると，膨張による強度低下が生 じ，粘性土の場合ほど排脱石高抢よび高炉スラグの添加

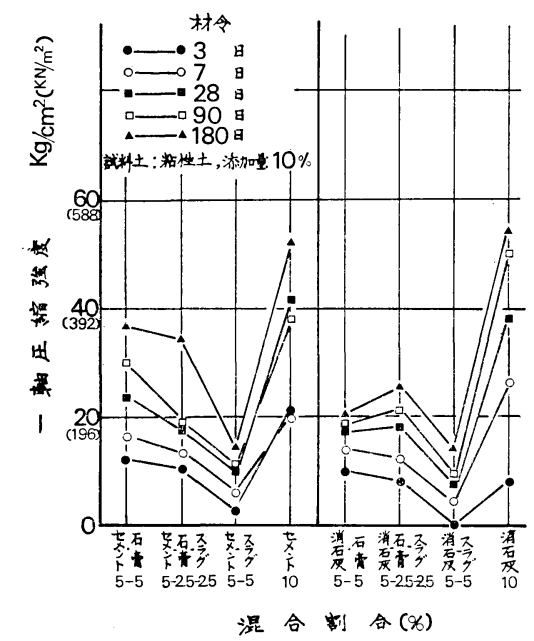

図一6 各種安定処理土 (試料土 : 粘性土, 安定材添 加量 : 10\%）の安定材の混合割合と一軸圧縮 強度の関係

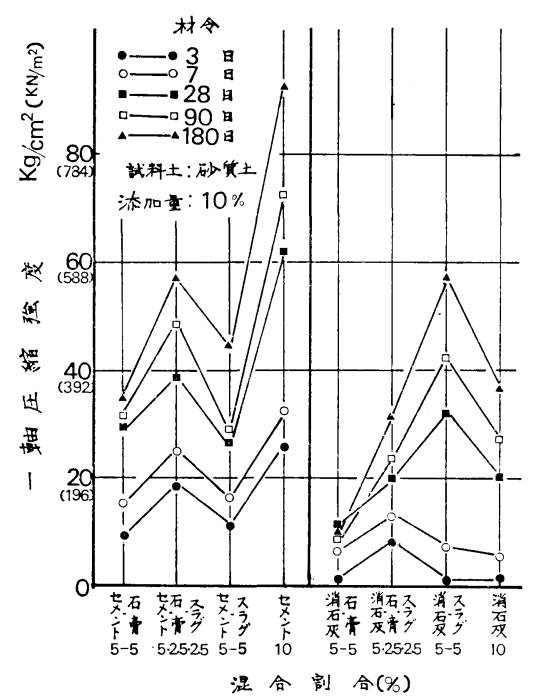

図一7 各種安定処理土（試料土：砂質土, 安定材添 加量：10\%）の安定材の混合割合と一軸圧縮 強度の関係 
による効果は期待できない，砂質土における消石灰一高 炉スラグ処理土が消石灰処理土と比べて著しく大きな長 期強度を示すことから明らかなように，本実験使用し た粘性土および砂質土においては，高炉スラグの潜在水 硬性を発揮させるためのアルカリ刺激材としては, ポル トランドセメントより消石灰の方が効果的である。この ことは締固め安定処理土においては添加量 10\% 程度の ポルトランドセメントの水和により遊離される石灰量で は高炬スラグのアルカリ刺激材の量として不十分である ことを示している．また，図一6 掠よび図一7 に示すよ うに安定材添加量 10\% の場合に抢いては，添加量 20\% の場合ほど初期材令におけるエトリンガイト生成の効果 が現われていないが，混合割合と強度の関係は添加量 $20 \%$ の場合と同様の傾向を示す.

\section{（2）体 積 膨張}

図一8 は各種処理土の体積膨張率と材令の関係を示し たものである．消石灰をアルカリ刺激材として使用した 処理土注，セメントを使用した処理土よりも排脱石高添 加量の多い混合割合において大きな膨張を示す．この傾 向は土粒子間に粘着力をもたない砂質土において特に顕 著である。また，図一8より明らかなように，最大の膨 張を示す砂質土の消石灰一排脱石高処理土 (10\%-10\%) を除いて, 膨張は 3 日材令までにほほ終了し, その後変 化がみられないのが特徴である。

石高添加量の多、混合割合のものは大きな膨張を示 す. 石膏添加量の多い混合割合のものではエトリンガイ トの生成量が多いことが示差熱分析掞よび X 線回折に よって認められているので, 膨張量とエトリンガイトの 生成量との間には関係があるものと思われる。しかし， 粘性土と砂質土とでは膨張特性が大きく異なることから 考えて，エトリンガイトの生成量および形態だけでな

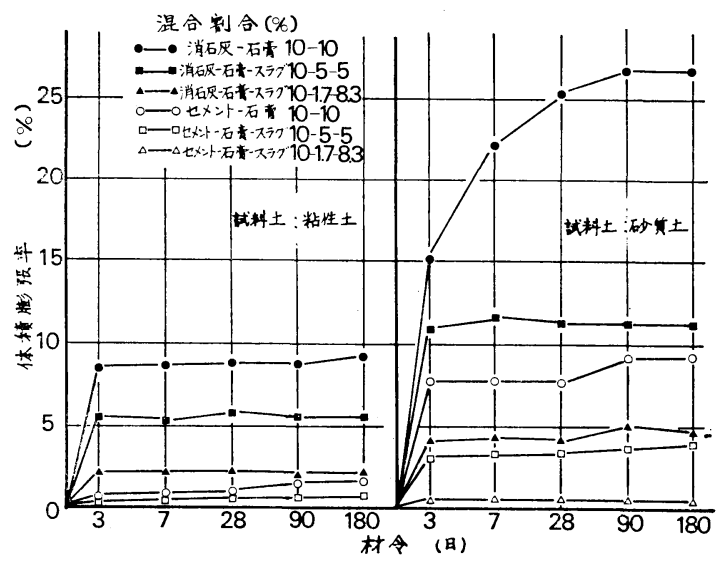

图一8 各種安定処理土 (試料土 : 粘性土および砂質 土, 安定材添加量 : 20\%) の体積膨張率と材 令の関係
く，土粒子間の粘着力および処理土の空嚐量により膨張 量は大きく相違するものと思われる。したがって，本実 験結果より，膨張とエトリンガイトの生成との関倸につ いて明確な結論を得ることはできない。

\section{4. 消石灰（またはセメント）-排脱石膏一高师 スラグ処理土における反応生成物}

\section{（1） 示差熱分析}

a）消石灰および消石灰一高炉スラグ処理土の DTA 曲線

図一9 および 図一10 に示すように粘性土拉よび砂質 土を使用した消石灰一高炉スラグ処理土 (10\%-10\%)の DTA 曲線にみられる $150^{\circ} \mathrm{C}$ および $170^{\circ} \mathrm{C}$ の吸熱ピー クはそれぞれケイ酸カルシウム水和物およびアルミン酸 カルシウム水和物によるものと思われる．また，砂質土 の消石灰一高炉スラグ処理土においては，28 日材令以後 に加水ゲーレナイトによるものと思われる $220^{\circ} \mathrm{C}$ におけ る吸熱ピークが存在する．しかし，消石灰処理土（図一 11 参照）には $220^{\circ} \mathrm{C}$ におけるピークはみられない。

Strätling ${ }^{5)}$ および有泉 ${ }^{6}$ は，それぞれ焼成カオリンと 石灰との反応およびアロファン，加水八ロイサイトと石 灰との反応に拉いて加水ゲーレナイトが生成したことを 明らかにしている. 本実験結果より反応性アルミナを多 く含有する高炉スラグを添加することにより砂質土にお

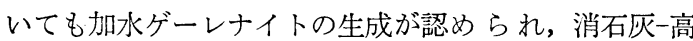
炉スラグ処理土の 28 日材令以後に抢ける著しい強度增 加にはこの加水ゲーレナイトの生成が大きな役制を果た
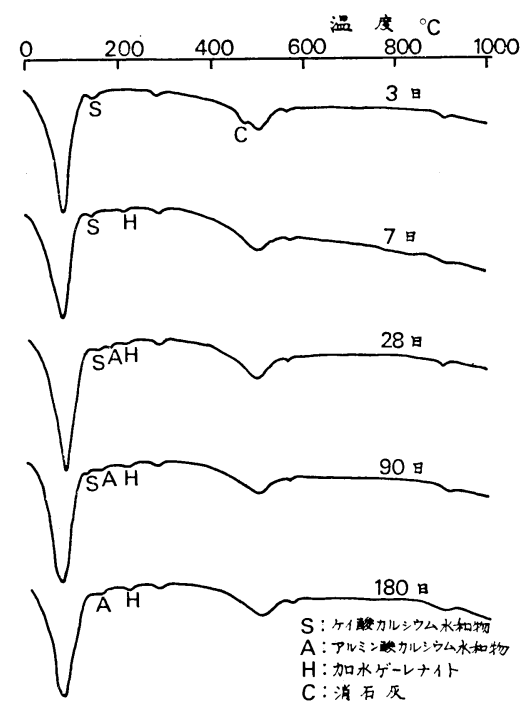

図一9消石灰一高炉スラグ処理土（試料土：粘性土, 消石灰-スラグ(10\%-10\%)) の各材令におけ る DTA 曲線 

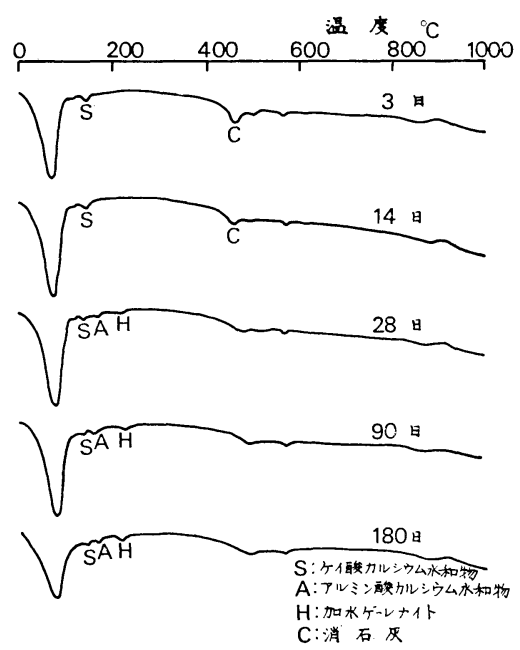

図一10 消石灰-高炉スラグ処理土 (試料土：砂質土, 消石灰ースラグ(10\%-10\%)) の各材令におけ る DTA 曲線
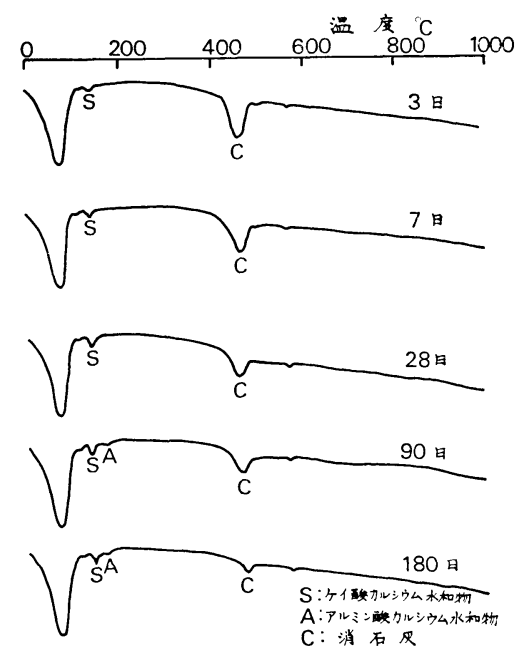

図一11 消石灰処理土（試料土：砂質土, 添加量 : 20 \%）の各材令における DTA 曲線

していると思われる7). 一方, 図一12 に示すようにセメ ントー高炉スラグ処理土 (10\%-10\%)の DTA 曲線には, 消石灰一高炉スラグ処理土において存在した反応生成物 のピークがみられない.

b）消石灰一排脱石膏処理土の DTA 曲線

図一13 および 図一14 は，粘性土および砂質土を使用 した消石灰-排脱石高処理土 (10\%-10\%)の DTA 曲線 を示したものである、粘性土にお゙いてはエトリンガイト の大きな吸熱ピーク $\left(120^{\circ} \mathrm{C}\right)$ が初期材令よりみられる が，長期にわたるピーク高さの変化は顕著ではない．石 高の吸熱ピーク $\left(140^{\circ} \mathrm{C}\right)$ は材令とともに減少している が，長期材令においても明確に認められる．このことよ り，粘性土を使用した消石灰一排脱石膏処理土における
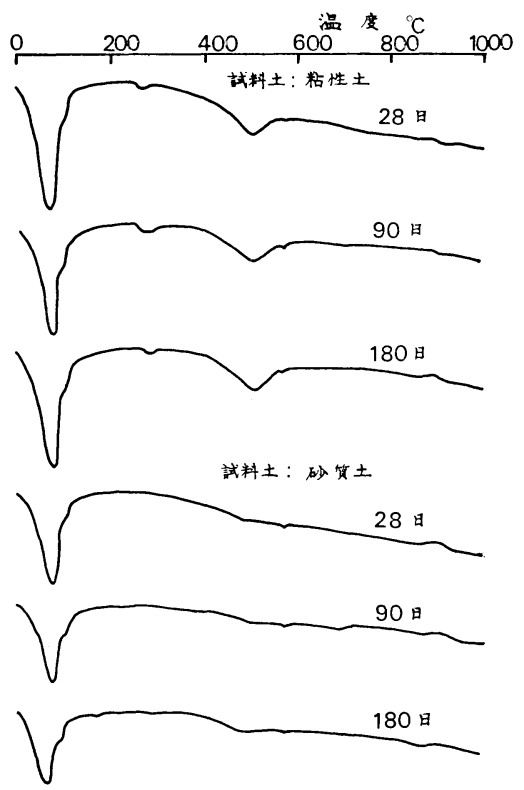

図一12 セメントー高炉スラグ処理土（試料土 : 粘性土 および砂質土，七メントースラグ (10\%-10 \%)）の各材令における DTA 曲線
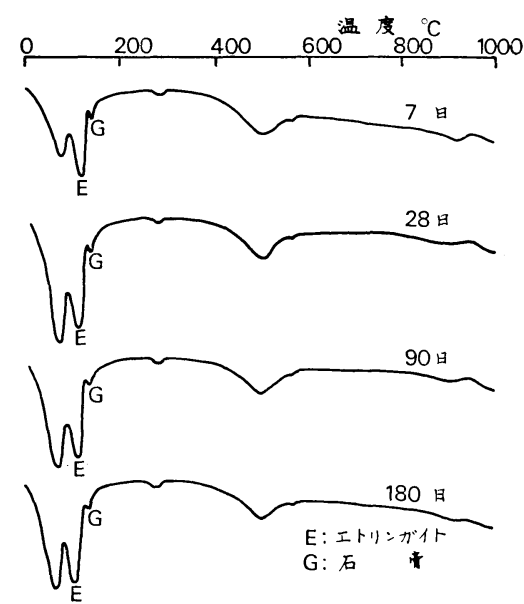

図一13 消石灰-排脱石亭処理土 (試料土 : 粘性土, 消 石灰一石青 $(10 \%-10 \%))$ の各材令における DTA 曲線

初期強度の増加は，エトリンガイトの生成によるもので あることがわかる (図一2参照). 一方，粘性土と同様に エトリンガイトの大きな吸熱ピークを示す砂質土におい て, 初期材令の強度がきわめて小さいのはエトリンガイ トの生成によってもたらされる膨張によるものと思われ る (図一4 および 図一8 参照).

消石灰（またはセメント)-排脱石膏処理土において石 育の消石灰（またはセメント）に対する比が 1 の場合の DTA 曲線には，消石灰（またはセメント）処理土にお いて存在するケイ酸カルシウム水和物およびアルミン酸 カルシウム水和物などの石灰と粘土間の反応による生成 

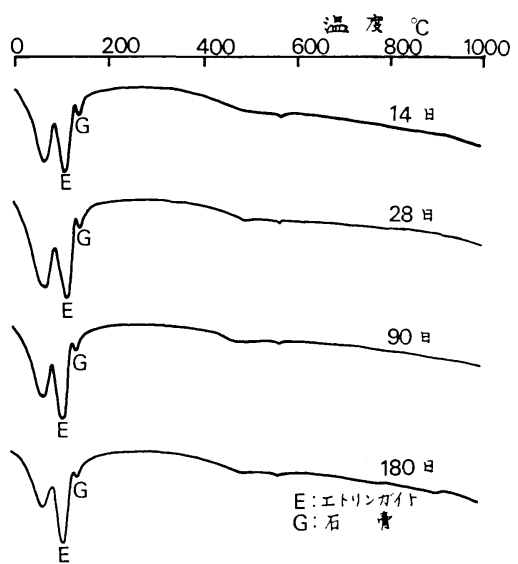

図一14 消石灰-排脱石高奶理土（試料土：砂質土，消 石灰-石高 $(10 \%-10 \%))$ の各材令における DTA 曲線
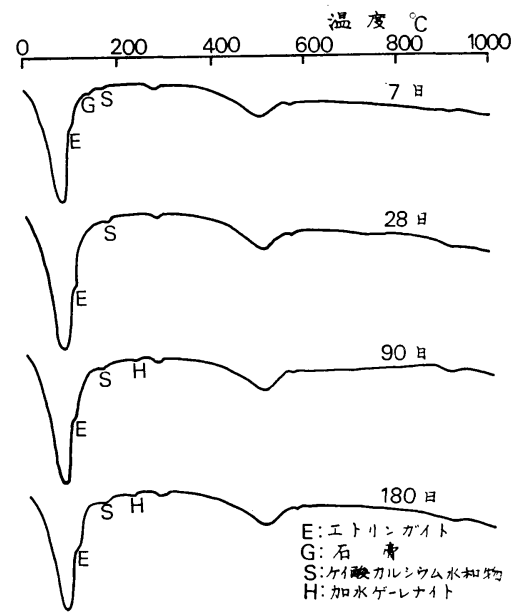

図一15 消石灰-排脱石高一高炉スラグ処理土（試料土： 粘性土，消石灰-石京-スラグ (10\%-1.7\%-8.3 \%)）の各材令における DTA 曲線

物のピークがみられないことが特徴である.

c） 消石灰-排脱石高-高炉スラグ処理土の

DTA 曲線

図一15 および 図一16 はそれぞれ粘性土を使用 した消石灰-排脱石高一高炉スラグ処理土における 消石灰一石亮一スラグ (10\%-1.7\%-8.3\%) および 消石灰一石育-スラグ(10\%-5\%-5\%) の DTA 曲 線を示したものである. 石亮量の多い消石灰一石 高-スラグ (10\%-5\%-5\%) の DTA 曲線は, 石膏 量の少ない消石灰-石育-スラグ (10\%-1.7\%-8.3 \%)よりもかなり大きなエトリンガイトの吸熱ピ ーク $\left(120^{\circ} \mathrm{C}\right)$ を示す. さらに, 両処理土の DTA 曲線においてみられる特徵は, 石高量の少ない混 合割合である消石灰-石膏-スラグ (10\%-1.7\%8.3\%)にはエトリンガイトとともにケイ酸カル
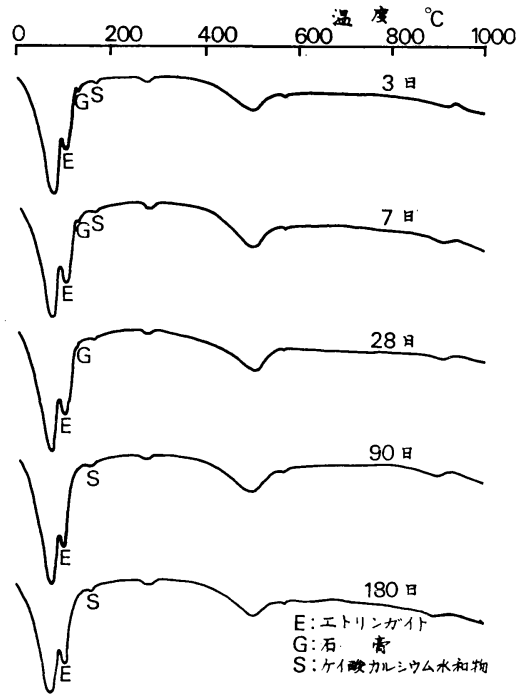

図一16 消石灰-排脱石旁一高炉スラグ処理土（試料土： 粘性土，消石灰一石亭-スラグ (10\%-5\%-5\%)) の各材令における DTA 曲線

シウム水和物 $\left(150^{\circ} \mathrm{C}\right)$, アルミン酸カルシウム水和物 $\left(170^{\circ} \mathrm{C}\right)$ および加水ゲーレナイト $\left(220^{\circ} \mathrm{C}\right)$ が顕著にみら れることである.このような両処理土間に拈ける反応生 成物の相違が消石灰一石膏-スラグ (10\%-1.7\%-8.3\%) では長期材令における強度増加が著しく, 消石灰一石高 スラグ (10\%-5\%-5\%) では初期材令に打ける強度の発 生が顕著であるという強度発生特性として現われている ものと思われる (図一2 参照).

\section{(2) $\mathbf{X}$ 線回折}

図一17 は粘性土を使用した各種安定処理土の材令 90 日における X 線回折図を示したものである.消石灰一排 脱石膏処理土 (10\%-10\%) および消石灰-排脱石高一高炉 スラグ処理土 (10\%-5\%-5\%) ともに 7 日以後の各材令

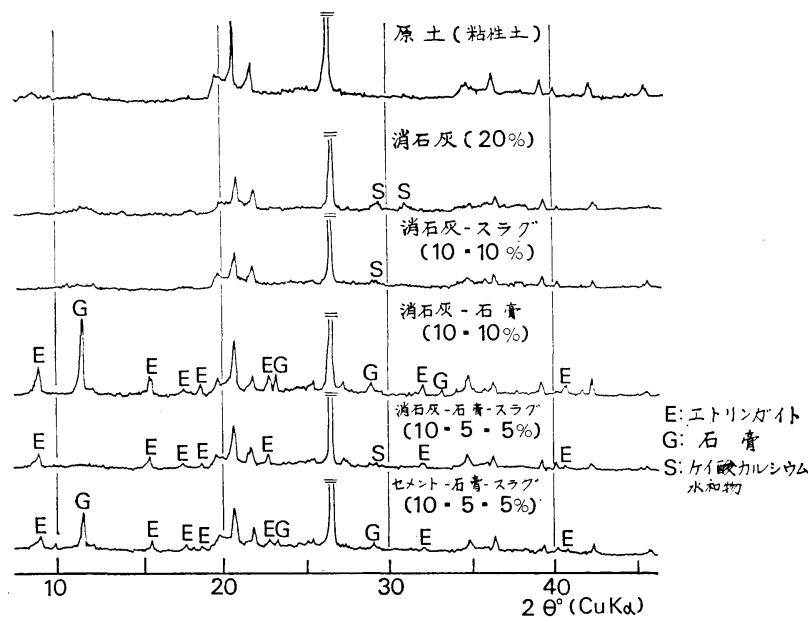

図一17 各種安定処理土 (試料土 : 粘性土, 安定材添加量 : 20\%) の材令 90 日における $\mathrm{X}$ 線回折図 
においてエトリンガイトの明確なピークを示す. 材令 90 日に损いて石膏のピークがすでに存在しない消石灰一排 脱石膏一高炉スラグ処理土 (10\%-5\%-5\%) はエトリンガ イトとともに $3.04 \AA$ に扔けるケイ酸カルシウム水和物 の小さいピークが存在する.これは示差熱分析の結果と 一致する (図一16 参照).

\section{（3） pH 試 験}

図一18 および 図一19 は粘性土および砂質土を使用乙 た各種安定処理土の $\mathrm{pH}$ と材令の関倸を示したものであ る.

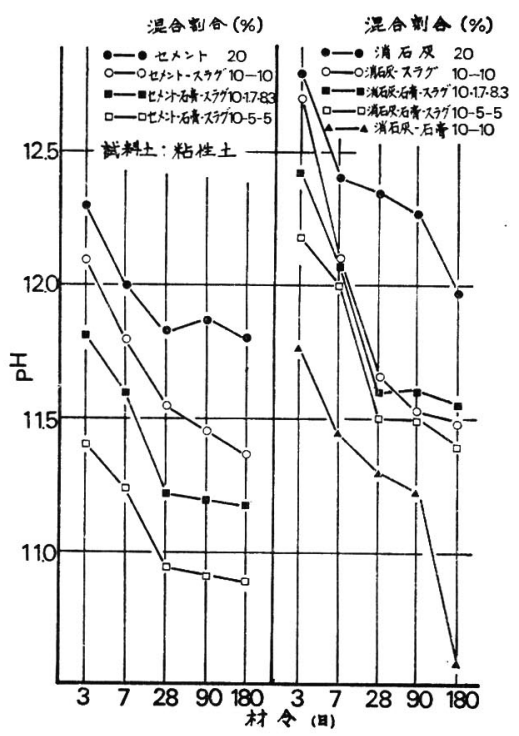

図一18 各種安定処理土 (試料土: 粘性土, 安定材添加 量 : 20\%）の pH と材令との関係

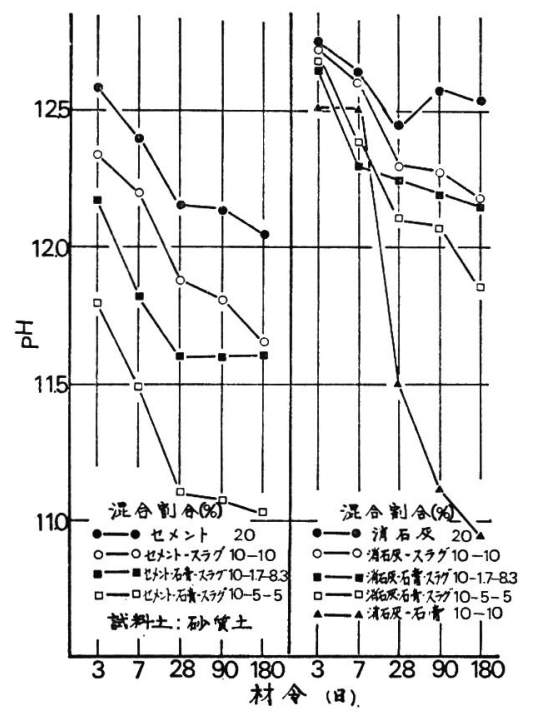

图一19 各種安定処理土 (試料土 : 砂質土, 安定材添加 量 : 20\%) の pH と材令の関係
粘性土を使用した消石灰一排脱石亮処理土(10\%-10\%) の $\mathrm{pH}$ 值は 3 日材令において 11.7 とすでに低く, 3 日 材令以後も急激に低下し続ける。また，砂質土において は 7 日材令までは消石灰を使用した各種処理土間の $\mathrm{pH}$ 值はいずれも 12.5 程度であるが，消石灰一排脱石高処理 土 (10\%-10\%) の $\mathrm{pH}$ 值は 7 日材令以後急激に低下寸 る.このことより石膏の添加量の多い混合割合のもので はエトリンガイト生成が初期材令から非常に活発であり その後も継続していることがわかる．また，エトリンガ イト生成により多量の石灰が消費されるため, 石育添加 量の多い混合割合のものでは Eades および $\mathrm{Grim}^{8)}$ に よって指摘されている粘土と石灰との間の反応を継続さ せるのに必要である高アルカリ状態を維持できなくなる ために，ケイ酸カルシウム水和物およびアルミン酸カル シウム水和物を生成する反応が抑制されるものと思われ る.

さらに，セメントー高炉スラグ処理土 (10\%-10\%)の $\mathrm{pH}$ 值は, 消石灰一高炉スラグ処理土 (10\%-10\%) と比 較して低い。この低い $\mathrm{pH}$ 值のためにセメントー高炉ス ラグ処理土では消石灰-高炉スラグ処理土と比較して高 炉スラグの潜在水硬性が十分に発揮されないものと思わ れる (図一3 および 図一12 参照)。

\section{（4）走查型電子顕微鏡による観察}

a) 消石灰一排脱石高処理土の SEM 像

写真一2,3 および 写真一 4 は砂質土を使用した消石 灰一排脱石膏処理土 (安定材添加量：20\%) に抢ける消石 灰一石亮間の混合割合の相違によるエトリンガイトの形 態の変化を示したものである. これらの写真より, 添加 する消石灰と石高の混合割合によって生成するエトリン ガイトの形態および量がかなり異なることがわかる．消 石灰：石高 $(1: 1)$ のものは他の混合割合のものに比べ てエトリンガイトの結晶成長が特に著しく， 7 日材令に おいて $1 \mu \mathrm{m}$ 程度のゲル状 (写真一3 参照) であったも のが, 写真一5 に示すように 3 か月材令では $30 \mu \mathrm{m}$ 程度 の細長い針状結晶に成長している，さらに，消石灰：石

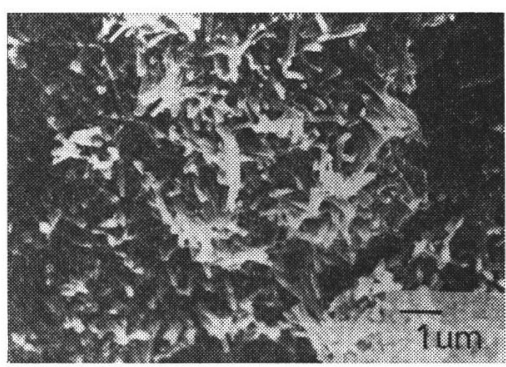

写真一2 消石灰-排脱石膏処理土（試料土 : 砂質土, 添 加量：20\%, 消石灰：石衰 $(1: 3)$, 材令 7 日) の SEM 像 


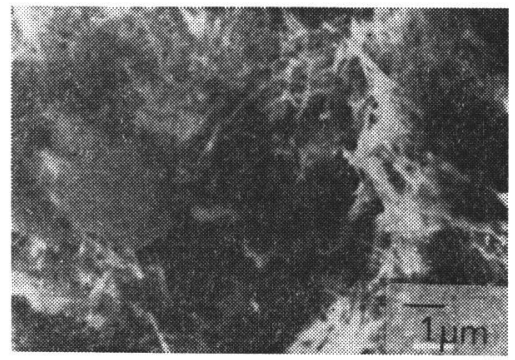

写真一3 消石灰-排脱石高処理土（試料土：砂質土, 添 加量: $20 \%$, 消石灰: 石膏 (1:3), 材令 7 日) の SEM 像

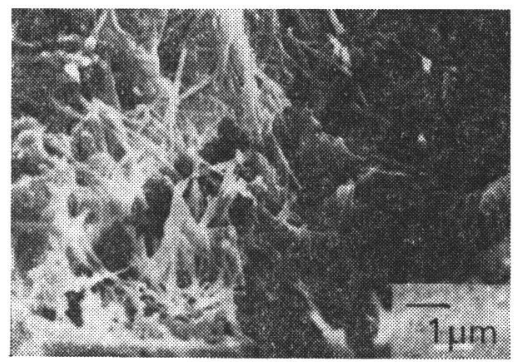

写真一4 消石灰-排脱石膏処理土（試料土：砂質土, 添 加量: $20 \%$, 消石灰: 石膏 (3:1), 材令 7 日) の SEM 像

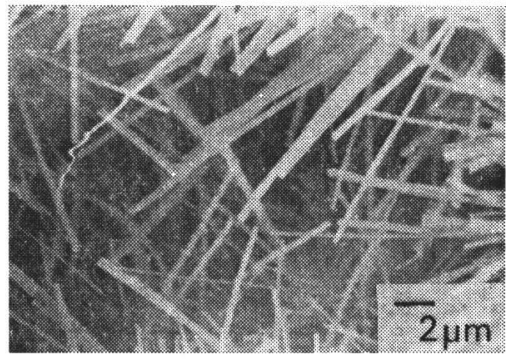

写真一5 消石灰-排脱石膏処理土 (試料土 : 砂質土, 添 加量 : $20 \%$, 消石灰 : 石膏 (1: 1), 材 令 90 日) の SEM 像

膏 $(3: 1)$ ののは，図一20 に示す砂質土を使用した消 石灰一排脱石高処理土の DTA 曲線からも明らかなよう に初期材令のうちに添加された石高がほとんど消費され てしまうため，長期材令において写真一6に示すモノサ ルフェート水和物と思われる薄片状の生成物 が存在す る. 次に, 写真一7 は粘性土を使用した消石灰一排脱石衰 処理土 (10\%-10\%) におけるエトリンガイトの形態を示 したものである. 粘性土を使用した消石扊一排脱石高処 理土において生成するエトリンガイトの形態は, 砂質士 の場合と異なり $1 \mu \mathrm{m} \sim 2 \mu \mathrm{m}$ の針状であり, これらのエ トリンガイトは粘土鉱物と密着して生成しているのが特 徵である. このように, $1 \mu \mathrm{m} \sim 2 \mu \mathrm{m}$ 程度の微細なエト リンガイトは土粒子間の空隚を充填し, エトリンガイト の絡み合いにより土粒子間に固結力を与えるようであ
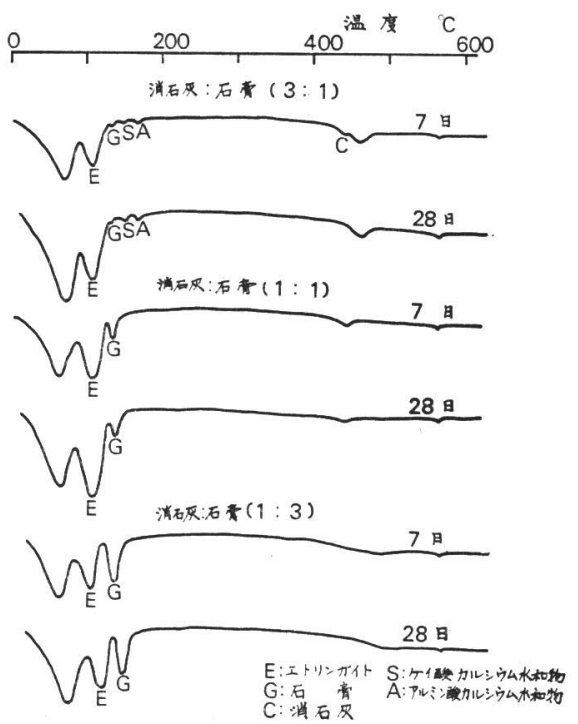

図一20 消石灰一排脱石亳処理土 (試料土：砂質土, 安定 材添加量 : 20\%) の DTA 曲線

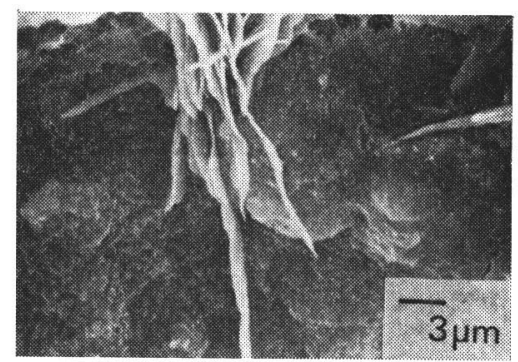

写真一6 消石灰-排脱石亳好理土 (試料土 : 砂質土, 添 加量 : $20 \%$, 消石灰 : 石亳 $(3: 1)$, 材令 90 日) の SEM 像

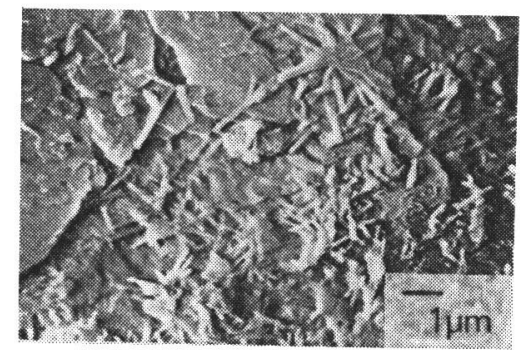

写真一7 消石灰-排脱石高処理土 (試料土 : 粘性土, 消石灰-石亳 (10\%-10\%), 材命 28 日) の SEM 像

る.このような砂僙土および粘性土を使用した処理土に おいてみられるエトリンガイトの形態の相違が両処理土 の強度発生状況の相違として現われるものと思われる. また，粘性土を使用したセメントー排脱石高処理士（10 \%-10\%)では全体としてのエトリンガイトの生成量は消 石灰一排脱石膏処理土と比較して少ない上うであるが， 比較的大きな石高粒子が粘土と接触している部分（写真 


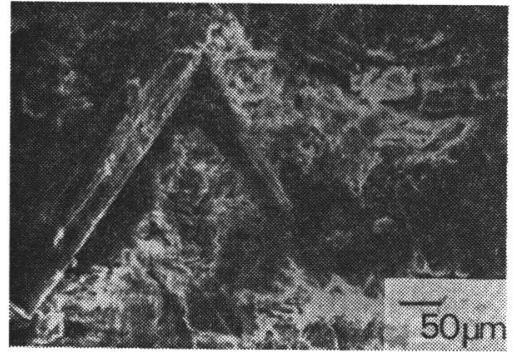

写真一8 セメント-排脱石膏奶理土（試料土：粘性 土, セメント-石亳 (10\%-10\%), 材令 7 日) の SEM 像

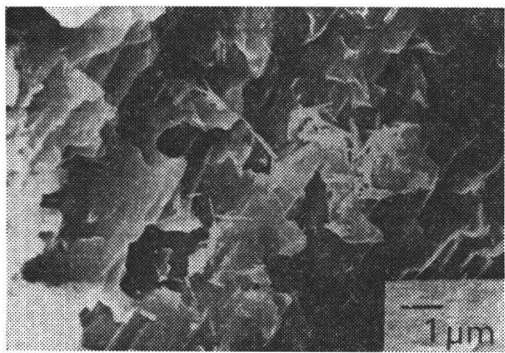

写真一9 セメントー排脱石膏処理土（試料土：粘性土, セメントー石亳 (10\%-10\%), 材令 7 日，石 膏粒子表面) の SEM 像

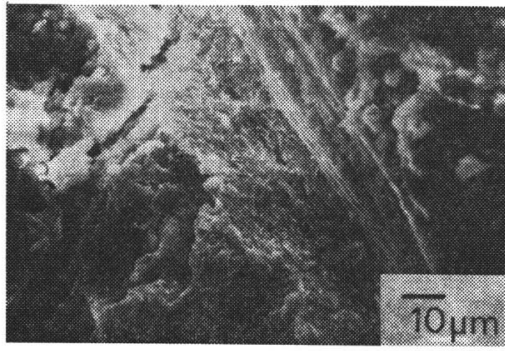

写真一10 セメント-排脱石亳処理土（試料土：粘性 土, セメント-石高 $(10 \%-10 \%)$, 材令 7 日) の SEM 像

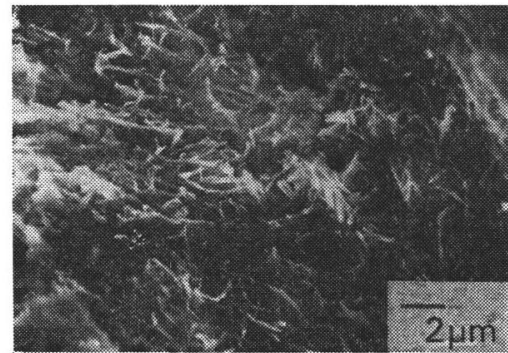

写真一11 セメントー排脱石膏処理土（試料土：粘 性土, セメントー石亳(10\%-10\%), 材令 7 日) の SEM 像

一8）においては石膏粒子表面（写真一9）が著しく侵食 されており，侵食された石高粒子の周辺に 写真一10お よび 写真一11 に示すような $1 \mu \mathrm{m} \sim 2 \mu \mathrm{m}$ の微細なエト リンガイトが多数生成しているのが確認された。

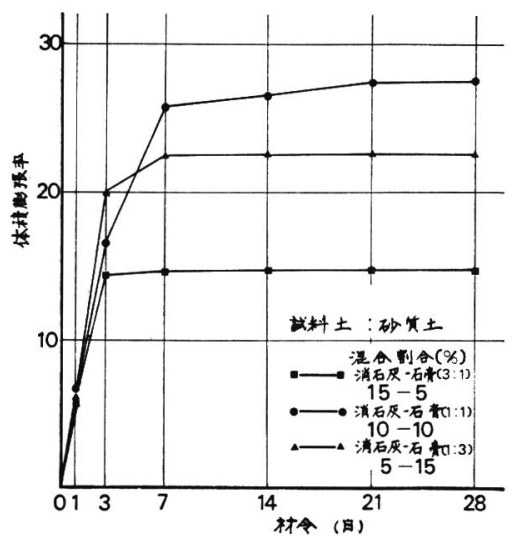

図一21 消石灰-排脱石亳処理土 (試料土 : 砂質土, 安 定材添加量 : 20\%) の体積膨張と材令の関係

$\mathrm{Mehta}^{9), 10)}$ は石灰および石膏の飽和状態において生成 するエトリンガイトは $1 \mu \mathrm{m}$ 程度のコロイド状であり， 十分に水が供給される状況下ではこの微細なエトリンガ イトが膨張を引き起こすと指摘している. 図一21 に示 すように砂質土を使用した消石灰一排脱石亮処理土（安 定材添加量 : 20\%) においては, 消石灰 : 石膏 (1:1)の 混合割合のものが最大の膨張を示し, いずれの混合割合 のものも膨張 は 7 日材令までに終了する．このことよ り，膨張を引き起こすのは写真一2 および写真一 3 に示 すような初期材令において生成する $1 \mu \mathrm{m} \sim 2 \mu \mathrm{m}$ 程度の 微細なエトリンガイトによるものと思われる.さらに， 図一22 は消石灰 (またはセメント)-排脱石膏処理土(試 料土：粘性土および砂質土, 安定材添加量 : 20\%) の水 浸および非水浸時における体積膨張率を示したものであ る. 図一22 における水浸供試体は，6日閒恒温恒湿室内 においてポリエチレン袋中で密封養生したものを 24 時 間恒温水槽 $\left(20^{\circ} \mathrm{C}\right)$ に浸漬した後，再び密封養生を行う といら過程を 1 週ごとに繰り返したものである（膨張率

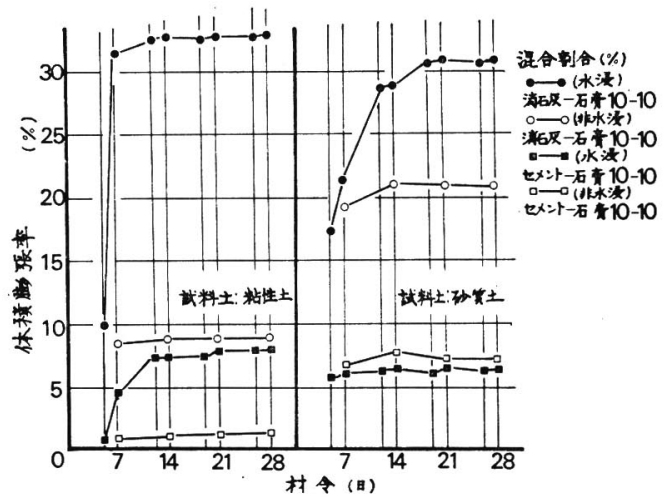

図一22 消石灰 (またはセメント)-排脱石高処理土（試 料土 : 粘性土および砂質土, 安定材添加量 : 20 \%)の水漫および非水漫時における体積膨張の 比較 
の測定は材令 1 日を基準としている). 砂質土のセメン 卜一排脱石膏処理土を除いていずれの供試体も第 1 回目 の水浸によって著しく大きな膨張が生ずる. しかし，以 後の浸漬時における膨張はほとんどみられない.これら の実験結果は本処理土において発生する膨張は初期材令 において多量に生成する微小なエトリンガイトの吸水膨 張によるものであることを示すようである.さらに, こ の事実はエトリンガイトの膨張機構に関する 2 つの説 (結晶成長説抒よび膨潤説) のうち膨潤説 9 ，10) の妥当性 を示唆するものと思われる.

b) 消石灰-排脱石高-高炬スラグ処理土の SEM 像

写真一12 および 写真一13 は, 砂質土を使用した消石 灰-排脱石膏一高炉スラグ処理土における消石灰一石膏-ス ラグ (10\%-5\%-5\%) および消石灰-石亮-スラグ (10\%-

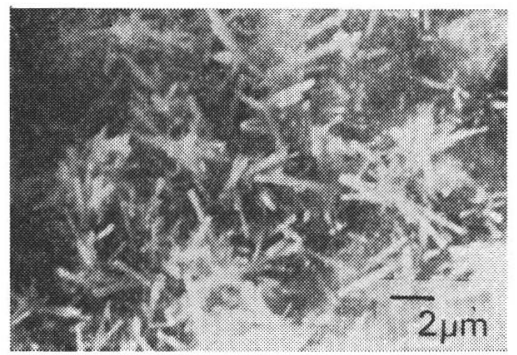

写真一12 消石灰-排脱石亳-高炉スラグ処理土（試料 土：砂質土, 消石灰-石高一スラグ (10\%$5 \%-5 \%)$ ，材令 28 日）の SEM 像

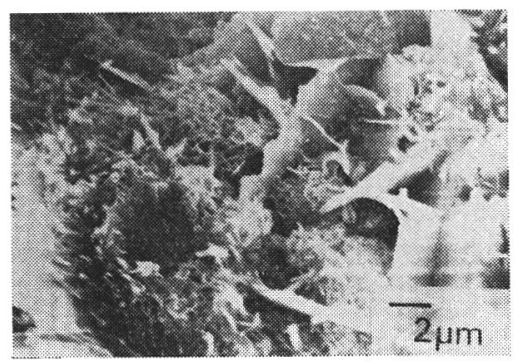

写真一13 消石灰-排脱石亳-高炉ス ラグ処理土（試料 土：砂質土，消石灰一石高-スラグ (10\%$1.7 \%-8.3 \%)$ ，材令 28 日）の SEM 像

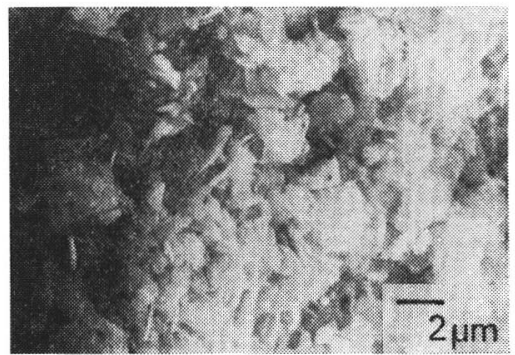

写真一14 消石灰一高炉スラグ処理土 (試料土 : 砂質 土, 消石灰-高炉スラグ (10\%-10\%), 材 令 28 日）の SEM 像
1.7\%-8.3\%）の反応生成物を示したものである.

石高量の多い混合割合である消石灰一石衰一スラグ (10 \%-5\%-5\%)には，写真一12 に示すようにエトリンガイ 卜以外の反応生成物はみられない，一方，石高量の少な い混合割合である消石灰-石膏-スラグ (10\%-1.7\%-8.3 \%) には，写真一13 に示すようにエトリンガイトの針状 結晶およびモノサルフェート水和物と思われる薄片状の 反応生成物の間に消石灰一高炉スラグ処理土（写真一14) においてみられるようなアルミン酸石灰水和物と思われ る板状の反応生成物および針状または網目状のケイ酸カ ルシウム水和物が共存している状況が認められる.これ は示差熱分析および X 線回折により得られた結果と同 様である。

\section{5. 結論}

消石灰(またはセメント)-排脱石育-高炉スラグ処理土 においては, 初期材令ではエトリンガイトの生成, 長期 材令では石灰またはセメントと粘土間の反応および高炉 水砕スラグの潜在水硬性による土粒子固結作用が主とし て強度に貢献していると思われる.さらに，これらの安 定処理土においては適用する土質および安定材の混合割 合によって反応生成物の種類および生成量が異なり，そ れに伴って強度および膨張特性も変化する.したがって このような多種類の安定材を使用するにあたっては, 適 用する土質に応じて適切な安定材の混合割合を選択する ことが重要である. 本論文においては締固め土を対象と しているが，エトリンガイトの生成により処理効果を期 待するこれらの安定処理ではエトリンガイトの生成機構 より考えて, 消石灰またはセメント単独では処理しにく い上うな高含水比あるいは有機質の土にも適用が可能で あり，さらにへドロおよびスラッジ処理へ適用した場合 には含水比の低下による処理効果とともにエトリンガイ トによる重金属の固定効果をも同時に期待できるものと 思われる. しかし，これら安定処理土中におけるエトリ ンガイトの気象作用（乾燥および湿潤の繰返し，温度変 化および空気中の炭酸ガスによる影響) に対する長期安 定性に関しては不明な点があり，またエトリンガイトの 生成による膨張によって生じた処理土内部の欠陥のため 耐久性（乾燥湿潤および凍結融解に対する抵抗性）およ び疲労特性が低下することも予想され，今後この点につ いて解明する必要があるものと思われる.

得られたおもな結果をまとめると次のようである.

（1）消石灰(またはセメント)-排脱石膏一高炉スラグ 処理土においては，初期材令ではエトリンガイトの生成 が主として強度に貢献しているため石膏量の多い混合割 合の強度の伸びが著しいが，28日材令以後では高炉スラ 
グの潜在水硬性による効果が顕著に現われてくる.ま た，高炉スラグの潜在水硬性を発揮させるために必要な アルカリ刺激材としてはポルトランドセメントより消石 灰の方が効果的である.

（2）セメントー排脱石亮一高炉スラグ処理土の膨張は 比較的小さいが, 消石灰一排脱石裏一高炉スラグ処理土は 石高添加量の多い配合において大きな膨張を示し，この 傾向は砂質土において顕著である.

（3）消石灰(またはセメント)-排脱石高-高炉スラグ 処理土において, 石膏添加量が多い場合にはエトリンガ イトの生成反応が卓越するため, ケイ酸カルシウム水和 物およびアルミン酸カルシウム水和物を生成するような 石灰（またはセメント）と粘土間の反応が抑制される傾 向にあり, 石膏量が少ない場合にのみエトリンガイトと ともにケイ酸カルシウム水和物およびアルミン酸カルシ ウム亦和物が共存している状況が認められる。このよう な反応生成物の相違が, 前者では初期強度が著しく, 後 者では長期材令における強度增加が顕著であるという強 度特性に現われている。

（4）消石灰（また沈メント)-排脱石高処理土にお いて, 添加する消石灰 (亡たはセメント) と石亮の混合 割合および粘性土と砂質土とでは生成するエトリンガイ トの形態および生成状況が異なり，それらが消石灰（ま たはセメント)-排脱石膏処理土の強度および膨張特性に 大きな影響を及ぼす.

\section{参考文 献}

1）有泉 昌・大場正男：アロファン質粘土の消石圧-石膏に よる化学的処理方法に関する研究 (5), 土木研究所報告, No. 119 , pp. 83 103, 1963.

2）有泉 昌・牧 隆正：アロファン質粘土の消石灰一石膏に よる化学的処理方法に関する研究(6), 土木研究所報告, No. 122 , pp. 35 60, 1964.

3）枷場重正・川村満紀ほか：脱硫副生産物による土質安定 処理, 土と基礎, No. 26, Vol. 5, pp. 11 16, 1978.

4) Tayler, D.H. : A new Technique for the study of Cement Hydration by Scanning Electron Microscopy, JTEVA, Vol. 5, No. 2, pp. 102 105, 1977.

5) Strätling, W. : Zement, 29, 427, 441, 455, 475, 1940.

6) 有泉 昌・藤崎邦弥： $2 \mathrm{CaO} \cdot \mathrm{Al}_{2} \mathrm{O}_{3} \cdot \mathrm{SiO}_{2} \cdot n \mathrm{H}_{2} \mathrm{O}$ の 2,3 の性質㧍よび加水八ロイサイトと $\mathrm{Ca}(\mathrm{OH})_{2}$ 溶液からの $2 \mathrm{CaO} \cdot \mathrm{Al}_{2} \mathrm{O}_{3} \cdot \mathrm{SiO}_{2} \cdot n \mathrm{H}_{2} \mathrm{O}$ の生成について, セメント技術 年報, No. 13 , pp. 182 188, 1959 .

7) Midgley, H.G. and P. Bhaskara $\mathrm{RaO}$ : Formation of Stratlingite, $2 \mathrm{CaO} \cdot \mathrm{SiO}_{2} \cdot \mathrm{Al}_{2} \mathrm{O}_{3} \cdot 8 \mathrm{H}_{2} \mathrm{O}$, in Relation to the Hydration of High Alumina Cement, Cement and Concrete Research, Vol. 8, pp. 169 172, 1978.

8) Eades, J.L. and R.E. Grim : A Quick Test to Determine Lime Requirements for Lime Stabilization, Highway Research Record, No. 139, pp. 61 72, 1966.

9) Mehta, P.K. : Mechanism of Expansion Associated Ettringite Formation, Cement and Concrete Research, Vol. 3, pp. 1 6, 1973.

10) Mehta, P.K. : Scanning Electron Micrographic Studies of Ettringite Formation, Cement and Concrete Research, Vol. 6, pp. 169 182, 1976. 